\title{
Giumbelli, E.; Rickli, J.; Toniol, R. (orgs.). (2019). Como as coisas importam: uma abordagem material de religião - textos de Birgit Meyer. Porto Alegre: Ed. da UFRGS. 334 p.
}

\author{
GABRIELLE B. CABRAL
}

UNIVERSIDADE FEDERAL DO RIO GRANDE DO SUL (UFRGS), PORTO ALEGRE/RS, BRASIL HTTPS://ORCID.ORG/OOOO-OOOI-8I82-770I

Por longo tempo, as Ciências Sociais guiaram-se por uma narrativa em que a religião estaria em decadência. A questão era assim compreendida pois o paradigma da secularização prescrevia o declínio da religião na vida social a partir da modernidade. Ecoando esta metanarrativa, as mídias e as novas tecnologias de comunicação eram vistas como possíveis agentes secularizantes. No entanto, as previsões dos analistas não se concretizaram e a religião permanece em evidência na esfera pública, tendo as mídias, neste contexto, um papel central.

À vista disso, os estudos de religião e mídia passam a ocupar uma posição central para a compreensão do posicionamento da religião na atualidade. Para além dos estudos sobre a utilização e apropriação das mídias de comunicação por atores religiosos, procura-se compreender o papel da religião enquanto mídia. Ou seja, parte-se do reconhecimento de que a religião implica em uma forma de comunicação mediada, na qual somente é possível manifestar a esfera do sagrado no mundo conhecido e visível por meio de mecanismos de mediação. Dessa forma, a comunicação com/sobre o sagrado sempre é performada através de algum suporte material, seja por meio de textos, ícones, arquitetura ou por meio do próprio corpo dos fiéis. É ainda importante notar que o foco nas materialidades oferece a oportunidade de ir além do conceito de crença, este ligado a análises que entendem religião como algo interiorizado, privilegiando a dimensão simbólica.

A abordagem material da religião tem como um de seus principais nomes a antropóloga alemã Birgit Meyer, acadêmica vinculada ao Departamento de Filosofia e Estudos Religiosos da Universidade de Utrecht, Holanda. Seu trabalho é enfim apresentado ao público brasileiro através do livro Como as coisas importam: uma abordagem material da religião, organizado por Emerson Giumbelli (UFRGS), João Rickli (UFPR) e Rodrigo Toniol (Unicamp) e publicado pela Editora da UFRGS. Apesar de já contar com alguns artigos traduzidos para a língua portuguesa, este é seu primeiro livro publicado em nosso idioma, fruto de extensos diálogos entre a autora e os organizadores. A coletânea traz artigos reflexivos que inspiram novos olhares teóricos e metodológicos sobre religião e mídia. 
Tendo realizado pesquisas principalmente entre os pentecostais de Gana, a autora interessa-se, sobretudo, pelo tema das materialidades presentes em contextos religiosos, como os usos da iconografia cristã, as produções audiovisuais de conteúdo religioso e até mesmo os equipamentos audiovisuais presentes nos cultos. Ao colocar a dimensão material como principal interesse de pesquisa, a questão dos processos de mediação e dos mediadores envolvidos na materialização do religioso torna-se central. Apesar de partir de contextos de pesquisa etnográfica no continente africano, a abordagem teórica abre-se para a reflexão em diferentes cenários, com base no debate oportunizado por projetos de pesquisa interdisciplinares coordenados pela autora. Assim, por assumirem um caráter bastante abrangente, as formulações são instrumentos de análise possíveis também para a realidade brasileira.

Os textos escolhidos para formar a coletânea partem de diferentes contextos - isto é, enquanto alguns capítulos são provenientes de capítulos introdutórios (como os capítulos 1 e 2), outros foram publicados originalmente como artigos e trazem desdobramentos mais recentes do pensamento da autora (ver capítulos 3, 5 e 6). O quarto capítulo, por outro lado, baseia-se na aula inaugural da autora na Cátedra de Estudos Religiosos na Universidade de Utrecht (2012), e destaca-se pela síntese dos aspectos centrais da abordagem material da religião.

Apesar dos contextos diversos, todos os capítulos concatenam as principais linhas argumentativas da autora. Uma noção que é abordada ao longo de todo o livro é a de forma sensorial, uma das principais formulações da autora. No decorrer da coletânea, a autora desenvolve o argumento de que “a religião pode ser mais bem analisada como uma prática de mediação, para qual as mídias, como tecnologias de representação empregadas pelos seres humanos, são intrínsecas” (:60-61). Para isso, é preciso que a noção de mídia seja ampliada para além dos meios de comunicação de massa, incluindo os demais mediadores que materializam o religioso através de práticas e objetos. A noção de formas sensoriais, por sua vez, inclui as mídias e pode ser entendida enquanto uma ferramenta analítica que procura compreender "como as mediações reúnem e vinculam as pessoas umas com as outras e com o transcendental" (:64). Em outras palavras, as formas sensoriais têm a ver com os modos pelos quais as mediações atuam na formação estética das pessoas.

A noção de formação estética é outro importante tema abordado pelo livro. Procurando dar atenção à questão da efetivação das comunidades, Meyer desenvolveu esta noção a partir de um diálogo com o conceito de "comunidade imaginada" de Benedict Anderson - discussão desenvolvida principalmente ao longo do primeiro capítulo. Primeiramente, optando pelo termo "estética", em substituição a "imaginada", a autora resgata a noção aristotélica de aisthesis, compreendendo estética enquanto uma forma de engajamento com o mundo por meio dos sentidos e, assim, partindo em direção a uma abordagem que abarque a experiência corporal. Sua segunda substituição - "comunidade" por "formação" - diz respeito a um entendimento de comunidade como um processo dinâmico e performativo que inclui tanto entidades sociais quanto processos de formação. De modo resumido, a noção de formação estética compreende o compartilhamento de formas específicas de engajamento sensorial com o mundo, constituindo sujeitos e comunidades.

Outra questão importante abordada pelo livro é a da indissociabilidade entre a religião e as coisas. Segundo a autora, a ideia de que há um antagonismo entre religião e materialidade, postura 
que norteou por muito tempo os estudos de religião, reside em uma noção universalizante de religião enquanto crença. Derivada da religiosidade protestante, a noção de "crença" privilegia uma ideia de religião ligada à interioridade e ao imaterial, acabando por dizer pouco sobre a religião na prática, isto é, sobre a presença tangível da religião no mundo. Dessa forma, a proposta de Birgit Meyer, em consonância às ideias de Hent De Vries, é a de "explorar as formas e elementos particulares, através dos quais a 'religião' é instanciada [...] no mundo" (:87). No entanto, como a autora deixa claro, ir além do antagonismo requer um constante exercício reflexivo e crítico para repensar as categorias de análise a partir da produção etnográfica (:95).

A autora ainda sugere que se busque uma abordagem integrada que não considere apenas o conteúdo, mas também a forma, noções que para ela são irredutíveis. Dessa maneira, para a abordagem material, religião se refere a "conjuntos específicos, autorizados e transmitidos de práticas e ideias que visam “ir além do ordinário”" (:187) que se manifesta no cotidiano, a partir de práticas empiricamente observáveis.

Para além da noção de religião como mediação discutida anteriormente, o livro aborda a questão de como é fabricada a presença extraordinária imediata vivenciada pelas pessoas. A chave para compreender essa questão de como o sagrado materializa-se no cotidiano dos fiéis é por meio da noção de mediação. A autora enfatiza que as mídias religiosas podem ser qualquer coisa que sirva de mediador do “acesso ao que está além do ordinário" (:190), e estão sujeitas a processos de autorização e autenticação. Nesse sentido, as formas sensoriais são importantes para entender a dimensão estética que orienta o envolvimento dos sentidos e da corporeidade dos fiéis e produzem a sensação de presença.

Ainda entre as preocupações da autora, há a questão do desenvolvimento de uma abordagem capaz de "capturar o uau!" (ver capítulo 6) - isto é, as sensações e emoções vivenciadas em contextos de saída do ordinário pelas pessoas em contexto religiosos - sem, no entanto, descartar a experiência como ilusão, tampouco como um efeito do "sobrenatural". O encanto, "emoção poderosa gerada através de um método padronizado" (:273), tem implicações nas relações de poder e pode ser observado e pesquisado na prática, o que estimulou a autora a formular sua noção de formas sensoriais, conceito que permite compreender a formação da experiência religiosa de um ponto de vista desde dentro, mas também sob um olhar externo.

Se após o estudo dos capítulos ainda restarem dúvidas a respeito dos conceitos básicos da abordagem material da religião, o leitor pode ainda esclarecer alguns pontos com uma entrevista concedida pela autora especialmente para este volume. Conduzido pelos organizadores do livro, o diálogo dá conta do intervalo entre os textos (sendo o mais recente de 2016) e seus desdobramentos posteriores, atualizando o leitor quanto à produção mais recente de Meyer e de seus atuais projetos de pesquisa. A autora também comenta a respeito de sua formação intelectual e suas pesquisas na África, bem como de suas expectativas em relação aos novos projetos.

Em suma, os argumentos da abordagem material da religião trazidos pelo livro são uma importante contribuição para o campo da Antropologia, em especial à Antropologia da Religião. Para além da mera inclusão das mídias nas análises, é preciso atentar para os jogos de poder envolvidos na apropriação, legitimação ou rejeição dessas mídias nos contextos estudados - processo este que passa por 
um entendimento de estética, sua relação com os sentidos e formas de engajar-se com o mundo. Em outras palavras, Birgit Meyer, através de sua abordagem material, nos dá excelente ferramenta analítica para compreender as performances que envolvem o processo de mediação e materialização do sagrado na vida cotidiana dos fiéis.

Gabrielle B. Cabral é Mestre em Antropologia Socialpela Universidade Federal do Rio Grande do Sul (UFRGS).

RECEBIDO: $08 / 10 / 2020$

APROVADO: $22 / 03 / 2021$ 